\title{
ARMENIA AND AZERBAIJAN IN THE ENP - MISSED OPPORTUNITIES?
}

Pawel STAWARZ, PhD

Faculty of Political Science and International Studies, University of Warsaw, Poland

pawel.stawarz@uw.edu.pl

\begin{abstract}
This article is devoted to the relations of the European Union with Armenia and Azerbaijan based on the European Neighbourhood Policy and the Eastern Partnership. Due to strategic location between Europe, the Middle East, as well as Central Asia the above mentioned instruments are very important for the European Union and its Member States, as well as Armenia and Azerbaijan. Azerbaijan's rich resources of crude oil and natural gas combined with the dominant role of the Russian Federation in the region make these two countries geopolitically important. In the context of the diversification of fuels in the EU energy sector this situation poses challenges for Brussels. Russia is the main supplier for many EU countries (the construction of the Nord Stream 2 gas pipeline shows that important EU members want to strengthen the observed realities, as does the Russian Federation) and the European diversification efforts are a threat to a stabilization of the energy dialogue with Moscow. The growing importance of the discussed countries of the South Caucasus has not caused significant interest among scholars in this issue. This is probably due to little interest in Armenia and Azerbaijan so far of major actors in the international political scene - with Russia as an exception. This text is an attempt to at least partially fill this gap.
\end{abstract}

Keywords: European Union, Armenia, Azerbaijan, European Neighborhood Policy, Eastern Partnership, energy resources.

\section{Introduction}

The policy of the European Union (EU) concerning the states that emerged from the Union of Soviet Socialist Republics (USSR) is not a common subject of scientific research. While relations between the EU and the Russian Federation (RF) have been explored to some extent, the EU's relations with Central Asia and the South Caucasus remain almost untouched, and this is one of the main reasons behind the topic of this article. The research field has been narrowed down to the EU's relations with two countries of the Southern Caucasus - Armenia and Azerbaijan. 
Azerbaijan and Georgia are the most important states for the European Union in this region, but a relatively large amount of research work has been carried out on Georgia, therefore the article is focused on Armenia and Azerbaijan. In addition, Armenia's activities (mainly regarding NagornoKarabakh) have a great impact on the position and activities of Azerbaijan (the country with the largest potential possible area of cooperation with the EU) on the international arena - also in the field of relations with the EU. The focus of research on those relations based on the European Neighborhood Policy (ENP) and the Eastern Partnership (EaP) is related to the fact that these are the latest initiatives of the European Union towards the Southern Caucasus; they comprehensively regulate mutual relations, and therefore have the most significant impact on the present and future relations of the indicated parties.

Being the subject of this article, the relations of the European Union with Armenia and Azerbaijan are considered through the prism of relations based on the ENP. The article also discusses interactions between those parties which are based on the EaP, initiated by Poland (RP) and Sweden, and which aimed at setting the direction for earlier EU activities in respect of its neighbouring states to the East and Southeast formed after the collapse of the USSR. The key questions to be answered are: Do the EU's relations with Armenia and Azerbaijan make optimal use of the potential for cooperation? What are the causes of the current state of affairs? Do the most likely scenario for the development of further relations assume progress, regression, or perhaps stagnation?

In answering these questions, it will be helpful to verify the following research hypothesis: The countries of the Southern Caucasus, especially Azerbaijan, are potentially key to the EU's energy security and as a transit territory. The supply of energy resources is one of the main elements of security in EU countries. The importance of these issues has not changed the fact that the European Union's relations with the region are not optimal. This state of affairs is the result of the perception of the South Caucasus countries through the prism of the Russia first principle, according to which all activities concerning Armenia and Azerbaijan should be analyzed by taking into account their impact on the EU's relations with the Russian Federation. In addition, Armenia and Azerbaijan are often perceived by decision makers (representing EU structures and Member States) as small, young states, formed after the collapse of the USSR, and which have virtually no significance in international relations. The two sides perceive international realities quite differently. In addition, major EU countries have different strategies for supplying Member States 
with energy resources. They assume that FR should be the main supplier of energy resources. This practically means giving up Azerbaijan's potential in this respect (also as a transit country). The purpose of this article is to show the place of Armenia and Azerbaijan in the EU's external activities, based on the ENP and the EaP. The text is time-bound - the EU's relationship with Armenia and Azerbaijan are considered only from the moment of entrance into force of regulations which have formed the ENP, and then have created the EaP; this limitation follows logically from the topic itself, as does the use of a territorial delimiter (the research area was narrowed down to Europe and Asia). In respect of Europe, the article is focused mainly on the territory of the EU member states and the RF. In respect of Asia, the focus is mainly on the South Caucasus countries and their neighboring states. A subject limiter was also used in the paper - the research concerns the EU's relations with Armenia and Azerbaijan, based on the ENP and EaP - as it results from the topic of this article.

The issues involved are considered from the perspective of neoliberal theory - the EU's activities towards Armenia and Azerbaijan, and Neorealist theory - the activities of those countries under the ENP and EaP. Descriptive method, as well as comparative, factor and scenario methods are used. The first of these is employed to analyze the source materials, which make it possible to determine the facts relevant to the studied issue. The second method is used to compare how Armenia and Azerbaijan cooperate with the EU, and to compare the achievements of each of them in different areas of cooperation. The factor method is used to examine the determinants affecting the potential of EU relations with Armenia and Azerbaijan, and the course thereof, which makes it possible to indicate the aforementioned factors and determine how they interact (positively or negatively), their weight, and with what intensity they affect the examined matter. Finally, the scenario method is used to determine three possibilities for the development of the phenomenon under study in the future, and to indicate which of these three is the most probable.

\section{EU relations with Armenia and Azerbaijan based on the European Neighborhood Policy and the Eastern Partnership}

Objectively, the European Union's policy towards the countries of the South Caucasus is very important to EU. Cooperation with Azerbaijan (to a lesser extent cooperation with Armenia) may be of particular importance for energy security - at a time when one of the EU's eastern neighbor, Russia, the main or one of the most important suppliers of natural gas and oil to many 
EU countries, conducts unpredictable foreign policy, contrary to international law (e.g. Annex Crimea). Under such conditions, energy security is of great importance to security in general.

The region is also potentially very important for the EU for other reasons. It is located on a narrow strip of land connecting the Black Sea with the Caspian Sea. It connects the EU (in the west, through its members on the Black Sea - Romania and Bulgaria) with the Middle East (through Iran to the south) and with the countries of Central Asia, rich in oil and gas deposits (to the east, through the Caspian Sea to Kazakhstan and Turkmenistan). The region adjoins to the Russian Federation on the north. If we notice that it borders Turkey on the southwest, we see that the South Caucasus lies at the crossroads of the most important political players in this part of the world (Stępniewski, 2011, p. 197). Most of the communication routes connecting the areas specified above cannot bypass the countries of the South Caucasus if they are to run in the shortest possible way, and thus the most economic one. China (PRC) has recognized this by proposing that the transport route associated with its enormous Belt and Road Initiative (the new Silk Road) should run through the South Caucasus (Fox, 2018).

The question therefore arises: why do not Azerbaijan and Armenia gain a higher position in the hierarchy of importance of EU external action? This reality makes research on the EU relations with the above countries very significant.

\section{Objectives of the European Neighborhood Policy and the Eastern Partnership}

When analyzing the EU's relations with Armenia and Azerbaijan, we must not omit one of its most important initiatives - the European Neighborhood Policy.

The main objectives of the ENP initiated by the European Commission (EC) and adopted on 12 May 2004 in its "Communication from the Commission European Neighborhood Policy Strategy Paper" (European Union, European Commission, 2004) are listed below. These are: an intensification of the EU's relations with Armenia and Azerbaijan and their transformation into relations of a unique, privileged nature; changes in those countries based on EU values (and compliance with them); administrative efficiency; support for good neighbourly principles; facilities for short-term travel; interparliamentary cooperation; and greater European Union's involvement in resolving the conflict between Armenia and Azerbaijan over Nagorno-Karabakh, as well as matters related to illegal migration and corruption. In the long term, the ENP was supposed to lead to increased stability, security and prosperity. However, the sole responsibility 
for implementing reforms to improve governance was to be borne by both South Caucasus countries. What became a novelty was the introduction of the more-for-more principle, according to which, in the event of greater involvement, Armenia and Azerbaijan would receive greater support from the EU, including financial support. Such differentiation was possible due to individually negotiated action plans (Kapuśniak, 2010, p. 26). The most important economic goals included actions for: introducing and consolidating the free market economy in both countries, sustainable economic growth, and economic reforms. The more specific objectives were: agreements with Armenia and Azerbaijan establishing a Deep and Comprehensive Free Trade Area (DCFTA); the conclusion of multilateral agreements in the fields of energy and transport, and the development of energy and transport networks; support for activities to encourage investors to invest funds in these countries; increased economic integration; cooperation in the most important areas; intensification of financial cooperation; increased employment; improvements in social services; and increased direct investment. Activities towards the two countries under the ENP were to lead to a equalization of disparities in the development of individual regions and to developments in agriculture and rural areas. Another goal was to strengthen cooperation and commercial connections, as it was also planned to sign Agreements on Conformity Assessment and Acceptance of Industrial Products (ACAA) (Stawarz, 2017, pp. 239242). Guidance on economic issues would seem to be more specific and realistic to implement. Other goals are of a directional nature. However, in both cases, there remains a drawback that, the institutions concerned are not able to enforce earlier obligations made by the parties under existing legal regulations.

Presented below are the main objectives that were to be achieved in cooperation with Armenia and Azerbaijan under the EaP (the first initiative of this type dedicated exclusively to the EU's neighbouring countries formed after the collapse of the USSR, which is thus better suited to their needs). The EaP project was established by the European Council at a summit held in Brussels on 19-20 June 2008, and the EC included the principles of its functioning in "Communication from the Commission to the European Parliament and the Council Eastern Partnership" (European Union, European Commission, 2008). Those principles are: tightening as much as possible relations between the EU and Armenia and Azerbaijan, carrying out reforms; deepening political cooperation; initiating and intensifying regional and cross-border cooperation, as well as developing relations based on compliance with international law; cooperating in matters 
of security and stability and supporting people-to-people contacts. The EaP was to become a new framework for the European Union's political cooperation with Armenia and Azerbaijan, and a space for the exchange of information and experience regarding the progress of these countries in the field of change, reform and modernization. It has also been an instrument through which the EU supports these activities. The main purpose of the association agreements, which were supposed to be the basis for EU's political cooperation with Armenia and Azerbaijan, was to bring about a convergence of the legal norms and standards in force with those in force in the European Union. Another goal was to intensify cooperation under the Common Foreign and Security Policy (CFSP) and the European Security and Defense Policy (ESDP) (Barabasz and Piechocki, 2012, pp. 261-262). Mobility and security have also been very important issues, and the purpose of the planned mobility and partnership agreements was mainly to control illegal immigration and to standardize the asylum system of both countries in accordance with EU standards (Stawarz, 2017, pp. 172-174).

The EU's bilateral relations with Armenia and Azerbaijan have been aimed at strengthening the ties between the two, which would lead to increased stability and prosperity in both countries. The purpose of multilateral cooperation, however, has been to create a space to help Armenia and Azerbaijan deal with problems they face together. Multilateral cooperation has been also intended to support bilateral cooperation.

One of the main goals of cooperation has been the implementation of EU values; security and defense reforms, and civilian control over the military one. Detailed, individual expectations were communicated to Armenia and Azerbaijan. In case of Armenia, a reference was made to: the need to strengthen the role of the Ombudsman; establishing legal regulations that would strengthen the independence of the courts and prosecution; improving the implementation of the country's anti-corruption strategy; improving the functioning of the public service; independence of the media; freedom of association; improving the penitentiary system system and reforming the police. The EC also pointed to the need to resolve the conflict with Azerbaijan regarding NagornoKarabakh. In addition to the issue of Nagorno-Karabakh in case of Azerbaijan, the list of expectations included: improving electoral law and conducting further changes in order to ensure a balance between the legislative and executive authorities; human rights issues, including a reorganization of the judicial apparatus, particularly with regard to its independence, activities aimed at strengthening civil society and its forms such as non-governmental organizations and 
associations, and the freedom of association and compliance therewith. (Kalicka-Mikołajczyk, 2013, p. 247).

Regarding the institutional provisions (a new institutional structure was to be introduced after the Association Agreements would have been signed), meetings of heads of state and heads of government were planned to happen every two years. Foreign ministers were to meet regularly. Their task was to control the progress made so far in the five main areas of cooperation. Other competencies included providing guidelines for further policy. Ministerial conferences were to be organized to support ministers' work (Mizerska-Wrotkowska, 2011, p. 50).

An equally, if not more, important element of the EaP is the EU's cooperation with Armenia and Azerbaijan on economic matters, where the main objectives are: to strengthen cooperation by establishing the DCFTA; to phase in integration of the economies of Armenia and Azerbaijan with the economy of the European Union through agreements establishing the DCFTA and through sectoral measures aimed at facilitating access by the partner countries to the EU market; to ensure long-term energy supply and transit; and to support economic development, including regional development, infrastructure, human capital and small and medium-sized enterprises (SMEs) (Kalicka-Mikołajczyk, 2013, pp. 244-245). Plans were made concerning the implementation of EU legislation on SMEs; increased access to financing; increased number of SMEs; improved information exchange between SMEs from the EU and EaP countries; the promotion of regional energy markets and efficiency in the field of energy and renewable energy sources; and the implementation of the southern energy corridor project. Cooperation in the field of taxes and public finances, as well as customs, was to be strengthened. A further goal was to initiate cooperation with the European Investment Bank (EIB), the International Monetary Fund (IMF) and the European Bank for Reconstruction and Development (EBRD) (Stawarz, 2017, pp. 250-252).

\section{Results of the European Neighborhood Policy and the Eastern Partnership}

Unfortunately, the results of the implementation of the ENP and the EaP have not proved optimal. In the case of political cooperation between the EU and Armenia, it should be noted that in the most important areas Armenia was willing to take action. As the effect there appeared changes expected by the European Union in the laws regulating issues in the indicated areas. The situation was worse, however, when it came to enforcing those legal provisions, especially in the fight against corruption. However, as indicated by the Eastern Partnership Index (Eastern 
Partnership Civil Society Forum, 2017, p. 115) in 2017, Armenia came third among the states covered by the Eastern Partnership, in terms of success in combating corruption, quite successfully There were also differences in the number of aspects of cooperation in a given field. The smallest numbers of cooperation aspects have been observed in democracy and the rule of law, as well as human rights and fundamental freedoms - in principle, the implementation of the legal provisions focused mainly on electoral procedures, although in this area as well, the most recent period of $\mathrm{EaP}$ implementation has brought about improvements - Armenia now ranks fourth (Eastern Partnership Civil Society Forum, 2017, p. 107), and in this area particular attention is merited by the high assessment of the independence of the judiciary (Eastern Partnership Civil Society Forum, 2017 , p. 113). Few achievements have been made in respect of regional cooperation, but there has been much wider cooperation in the areas of internal security and combating crime, concerning: the protection of the national borders; visa facilitation and readmission; combating organized crime, especially regarding child sexual exploitation, arms trafficking, human trafficking, money laundering, terrorism and the fight against drugs, as well as police and judicial cooperation. The fight against corruption mainly focused on increasing transparency regarding the revenues of government officials (Stawarz, 2017, pp. 216-217). In the case of economic cooperation, the best results have been achieved in such areas as: the liquidation of barriers to the trade in goods, and the principles of starting up and conducting business activity. Worse results have been observed in the field of competition policy, with the weakest results in the field of energy resources (Stawarz, 2017, pp. 281-282). In case of Azerbaijan, attention should be paid to the great successes it has achieved in implementing cooperation in the area of internal security and combating crime, in areas such as: border management; migration; combating organized crime in matters such as human trafficking; cooperation in criminal matters with the Commonwealth of Independent States countries and Turkey, Iran and Bulgaria; cybercrime; protecting children against sexual abuse; combating cross-border crime; the fight against drugs; combating money laundering; terrorism; legal assistance and legal relations in civil, family and criminal matters; data protection; and preventing the proliferation of weapons of mass destruction. The fight against corruption has been less effective, with implementation in such areas as: increased transparency in decision-making mechanisms; recruitment for the civil service; the national budget; the financing of political parties; public procurement; privatization; public administration bodies and the protection of witnesses and persons cooperating with the judiciary in corruption cases; limitations on the 
immunity of judges suspected of corruption (Stawarz, 2017, p. 218). The implementation of legal provisions in the field of democratization and human rights have received lower marks. As for economic cooperation, Azerbaijan has made significant achievements apart from the area of competition (Ostapenko, 2019). Also, the energy independence of the state deserves special attention - in this category, according to the Eastern Partnership Index, Azerbaijan ranks number one (Eastern Partnership Civil Society Forum, 2017, p. 142).

In summary, it can be observed that the effects of EU cooperation with Armenia and Azerbaijan under the ENP and EaP have been diverse, despite same assumptions and legal provisions. Compared to Armenia, Azerbaijan has made significant achievements in economic cooperation - in almost all major areas there is now a significant spectrum of areas of cooperation, and the implementation of made commitments is going well. In Armenia the situation is worse, which is largely due to the fact that the country has no deposits of energy resources, and that the infrastructure for gas transmission is almost entirely owned by subsidiaries of the Russian authorities, which are not enthusiastic about relations between the Post-Soviet countries and the EU. The situation is similar in other industries. As for political cooperation, both countries have made big commitments and achieved results in matters related to security although Azerbaijan decided on a larger area of cooperation in this field. Cooperation with the EU in the fight against corruption has not been as successful as it had been hoped for. There are also shortcomings in the areas of democracy and the rule of law, as well as human rights and fundamental freedoms. Although Armenia is carrying through on its commitments, they relate to only a very few issues, still it should be emphasized that the assessments made in this respect have improved recently. Azerbaijan's scope of commitments is greater, but not all of them have been successfully implemented. In respect to regional cooperation, Azerbaijan has achieved more than Armenia.

The fact that neither Azerbaijan nor Armenia has signed an association agreement, albeit for different reasons, has become the main failure of the $\mathrm{EU}$; an association agreement was to be the culmination of a certain stage of cooperation within the EaP. The decision by both countries not to sign have put cooperation under the EaP in a kind of limbo as regards the direction for further development ${ }^{24}$, and the EU can only react to this state of affairs to a certain extent. A

\footnotetext{
${ }^{24}$ With hope and optimism, the EU adopted the changes that occurred in Armenia as a result of the so-called Velvet Revolution of 2018. Because of mass protests by the Armenian community, Serż Sarkisjan, who had ruled for many years as president and then prime minister of Armenia, has resigned from his position. Opposition leader Nikol
} 
comprehensive and extended partnership agreement (CEPA) represents one such attempt. It does not intensify mutual relations to the same extent as the previously rejected proposal, but it does allow an intensification of cooperation in some areas, where it is possible despite Armenia's membership in the Eurasian Economic Union (EEU) (Sadowski, 2019). In case of Azerbaijan, advanced negotiations have been ongoing for several years regarding the content of a new comprehensive agreement to replace the PCA (European Union. European Council, Council of the European Union, 2019).

Thus, it can be seen that, in those areas defined by the ENP and the EaP, the EU's relations with Armenia and Azerbaijan have not been optimally developed. There are several reasons for this.

Firstly, when designing its policy towards Armenia and Azerbaijan, the EU have viewed them through the prism of neoliberal theory, and the goals and logic of the EU's cooperation were set accordingly. It was assumed that absolute profits were the most important, and that interrelationships would render war practically impossible. However, the reality of the location of Armenia and Azerbaijan is better explained by Neorealist theory, according to which the governments of both countries act, as well as Russia does. The most important elements are state security and relative profits. This means that the EU is nott an enough attractive partner for the governments of Armenia and Azerbaijan. What is most important for them is to ensure their own security and survival. That is why Armenia has chosen to strengthen its relations with Russia rather than the EU. The country knows that the RF is reasoning in accordance with Neorealist assumptions (as evident in Russia's war with Georgia in 2008 and the current situation in Ukraine) and in case of conflicting interests it is capable of resorting to force. As an ally, however, Russia can also provide real military support, as it did to Armenia during the latter's open armed conflict with Azerbaijan that began in the first half of the 1990s when the Armenian majority of Nagorno-

\footnotetext{
Pashinian has become the new prime minister. In the same year, as a result of early parliamentary elections, the supporting party have gained a majority. The new prime minister and the supporting forces declared they would introduce reforms for democratic systemic changes in the state and the modernization of state structures towards Western standards (Sadowski, 2019). Still, too little time has passed to determine whether those declarations will eventually become reality, although there have been many positive signals. If they do, this will affect the EU's relations with Armenia in a very significant and positive way, and which should also improve mutual relations. However, the Russian Federation, which still has very considerable political and economic influence in Armenia, may also act as a restraint, in part due to Armenia's unresolved conflict with Azerbaijan. These elements may cause that the potential for mutual relations will not be fully realised to a lesser extent than before.
} 
Karabakh, part of Azerbaijan, announced the territorial independence . Armenia supported the change, and this ultimately led to a war between the two countries (Carley, 1998). Although the "hot" phase of the conflict ended with a ceasefire signed in Bishkek on 5th May 1994 (Adamus, 2016), the dispute still has not been officially or actually resolved. On the basis of a fait accompli, part of the territory of Azerbaijan (Nagorno-Karabakh) remains outside its actual jurisdiction, while the Republic of Nagorno-Karabakh - proclaimed in 1991 - has not been recognized by any state (Jarosiewicz and Falkowski, 2016). The military victory over Azerbaijan (which caused Azerbaijan to lose control of part of its territory) was mainly the result of support, and especially military support, from Russia (very large supplies of modern weapons, and even the participation of military troops). Against this background, for Azerbaijan the EU is an unreliable entity as it will not attack another country, but in the event of a threat will only condemn the actions of the hostile state (the most radical measure the EU has decided on is sanctions - imposed over the conflict between Russia and Ukraine, but these are selective sanctions and so far they have not affected any change in Russian policy). This is why Azerbaijan focuses on its economic relations with the EU. The state is seeking the way to use this cooperation to strengthen its own position in the region, to be a more equal partner for Russia than Armenia, for which a side effect of Russia's support is heavy dependence on the RF. The Armenian authorities are aware that maintaining the current status quo regarding Nagorno-Karabakh, in the absence of formal grounds, is possible only thanks to the support of its very strong military and political protector, the Russian Federation. Russia, of course, is also aware, and therefore sets the conditions, making Armenia's foreign policy almost completely dependent on the will of the RF, and the country is economically-dependent, as well (most entities that are part of key sectors of the Armenian economy belong to enterprises associated with the Russian authorities; they were often transferred for symbolic amounts, e.g. the strategic pipeline connecting Armenia with Iran) (Polska Agencja Prasowa, 2006). Recent events related to the 'Velvet Revolution' have raised hope for change, or at least some modifications, in this regard. Thus, it is clear that, even if both countries of the South Caucasus are intensifying cooperation with the EU in a given field, they are doing so for reasons other than those envisaged by the ENP or EaP. Armenia and Azerbaijan have always considered what steps they should take from the perspective of increasing their own security.

One disadvantage of the ENP, and the EaP although to a lesser extent, is the underfunding of these initiatives, which does not have a mobilizing effect on the implementation of their 
assumptions (Benedyczak et al 2019, p. 8). This is a result of the fact that the European Union, and especially its most significant member states, have perceived (and to a lesser extent still perceive) Azerbaijan and Armenia as small, remote territories of little significance for.

Another disadvantage is that the general assumptions of the ENP are directed to both the eastern and southern neighbours of the EU, and they are thereby not ideally suited to any of them. However, this defect has been eliminated in the EaP.

The ENP and EaP also suffer from the fact that, unlike the programmes offered to the countries of Central and Eastern Europe, they do not hold out the promise of EU membership (Dassonville, 2019). There is no clear goal to be reached by ENP and EaP participants (the EaP offers a substitute goal of signing an association agreement, but neither Armenia nor Azerbaijan is interested in doing so). Such actions on the part of the EU confirm that its approach towards relations with Armenia and Azerbaijan relies on the rule that the states are not among those countries with which relations are a priority. This situation also stems from the Russia first principle, which is being followed, albeit to a lesser degree, in the EU's contacts with Armenia and Azerbaijan. The European Union gives primacy to Russia in the region, without taking more intensive actions - unlike the countries of Central and Eastern Europe before their accession to the EU.

In addition, the ENP and EaP agreements contain no effective instruments of mutual enforcement by the parties of the agreed arrangements. These appear only in the Eastern Partnership, and only after the conclusion of an association agreement. When Armenia joined the Eurasian Economic Union in 2015, it ruled out the signing of such an agreement - another example of how Russia's position vis-à-vis Armenia is stronger than that of the European Union. Armenia had fulfilled its obligations under the $\mathrm{EaP}$, and there seemed to be a real chance that it would have signed an association agreement. However, Russia opposed such a scenario, fearing that the EU would strengthen its position in relation to Armenia at Russia's expense, and managed to persuade Armenia to join the EEU, formed at the RF's initiative (Strzelecki, 2016), which has binded Armenia to Russia even more and at the same time prevented the conclusion of an agreement with the EU. Azerbaijan, which has a much stronger position in the region, has chosen independently not to sign an agreement with the EU. Considering the country's assets (mainly energy resources, pipelines and a convenient transit location), the Azerbaijan authorities have recognized that they have such a strong position, including relation to the EU, that it is more advantageous to maintain 
the status quo than to enter into an agreement with the European Union which would contain many problematic commitments.

The EU's cooperation with Armenia and Azerbaijan based on the ENP also involves negotiated individual action plans; this makes the ENP more suited to the needs of a given country, although it is still true that the overall assumptions lack precision as they are directed to neighbouring countries in both the south and the east.

The ENP and the EaP have brought some success. In case of Azerbaijan, these include its exemplary implementation of economic and security-related components. Armenia, on the other hand, has presented itself well in implementing programmes related to cooperation on security, and it has recently achieved good results in the areas of democracy and the rule of law, as well as human rights and fundamental freedoms. The abandoned NABUCCO pipeline project stands as confirmation of the importance of the region for the EU's energy security, but also of its failure to exploit the potential of Azerbaijan, which has ownership control over the oil and gas deposits in its territory and a good location as a transit country for energy resources from Central Asia (Wójcik, 2013). This has mainly been a consequence of the Russia first principle that guides the most important EU countries, and of the selecting by some of those countries (e.g. Germany) a different strategy for the supply of energy resources that is based mainly on cooperation with Russia $^{25}$. This further reinforces the effects of these two determinants, as they naturally support each other. Currently, a project similar to NABUCCO is being implemented successfully but by Azerbaijan, not the EU (Wójcik, 2013).

\section{Summary}

The facts discussed above allow to state that research hypothesis set out at the beginning of this article has been positively verified. Armenia and Azerbaijan have made a certain amount of progress in achieving some of the objectives of the ENP and the EaP, although their motivations have been different than these assumed by the EU, and mutual misunderstandings concerning expectations have damaged the intensity of cooperation. Of course, the EU is not a state, and will never be able to act like a state unless it is transformed into this type of entity at some point. But

\footnotetext{
${ }^{25}$ The effect of this approach is the Nord Stream gas pipeline and the construction of the controversial Nord Stream 2 gas pipeline through which gas will flow from Russia via the Baltic Sea to Germany and then to other EU countries. The gas pipeline bypasses countries such as Poland, Ukraine and Belarus.
} 
this does not mean that its policy towards Armenia and Azerbaijan should not be adjusted to become more effective. In this respect, it would be helpful if the European Union changed its perception of Armenia and Azerbaijan and quickly came to realize that these two countries are important for the development of the EU itself; one element of this would be to discontinue the application (this process has already been started) of the Russia first principle in the EU's policy.

In attempting to answer the last but not least of the questions posed at the article's beginning regarding the future of the EU's relations with Armenia and Azerbaijan as based on the ENP and the EaP, three scenarios are possible.

The first scenario implies that association agreements with the Union will not be concluded, and that the EU will lack initiative The countries concerned will not redefine the assumptions of their existing cooperation to change them in such a way that there will be a further chance for development (however in the case of Armenia, some measures have already been taken - the CEPA agreement. Also, Azerbaijan is negotiating a new agreement). This state of affairs is not $t$ favourable for either side. A lack of prospects for further development of cooperation deprives the parties of motivation to intensify their activities, and usually results in discouragement and the marginalization of mutual relations.

The second possibility for developing relations is regression, meaning that the parties withdraw from the stages of cooperation already achieved. This is obviously the least optimistic vision of how the situation may develop.

The third option is intensification of cooperation. This may require a change in Armenia's and/or Azerbaijan's decisions not to sign an association agreement, or the EU's decision, accepted by the countries concerned, to change the existing cooperation assumptions for the ones that are $\mathrm{e}$ attractive to the European Union, as well as Armenia and Azerbaijan (such steps have already been discussed).

Knowing the basic possibilities of how relations between the parties may develop, one should consider what factors are most crucial in determining the future direction of the current situation. Armenia and Azerbaijan are perceived by most of the most important EU countries in accordance with neoliberal theory. If this approach does not change radically, and if member states continue to perceive those countries as small, remote and insignificant for the EU, as well as located firmly within the Russian sphere of influence, then the scenario of stagnation may come true. It would also be favoured by the policy of basing the EU's supply of natural gas on 
cooperation with the RF, forced by a key EU country - Germany. In order for the stagnation scenario to fully happen, Armenia and Azerbaijan will also have to maintain cooperation with the EU in its current form. Russia should also continue its current policy towards these countries.

A change of government could be a determinant of the second scenario, especially in the most important EU countries, which leads to a positive assessment of the current Russian authorities and the wish to strengthen cooperation with that country. The growing importance of parties of this sort can now be observed in even the largest EU countries.

The third, most desirable variant of developing the EU's relations with Armenia and Azerbaijan, namely progress, requires a change in the European Union's approach towards the countries of the South Caucasus. This does not mean a complete reevaluation and change in perceptions of the South Caucasus in line with Neorealist theory, which would in any case seem to be impossible if we take into consideration that the EU is an international organization, not a state - that is, it is an entity for which neoliberalism is a natural way to view international relations. Nevertheless, if the EU wants to be effective, it has to take into account the realities of the regions which it desires to strengthen relations with, and in which it wants to be an important actor. Therefore, some elements of the Neorealist vision of international relations should be taken into account by the EU in its relations with Armenia and Azerbaijan, and this is possible provided the current governments of the main EU countries, or future governments after elections, change how they perceive the realities of Armenia and Azerbaijan.

Finally, it should be decided which of the above scenarios is the most likely. The key element in this respect is how the governments of the most important EU countries perceive the South Caucasus. Countries such as Poland know much better the realities of conducting policy in the immediate vicinity of Russia, and so it seems that they have the greatest responsibility as regards raising the awareness of Germany, France or Italy in this respect. In relation to Armenia and Azerbaijan, the policy of the most important EU state - Germany - is gradually beginning to change, but remains ambivalent. On the one hand, the state supports the sanctions imposed on the RF in connection with the conflict with Ukraine, which is also important for both countries of the South Caucasus, but on the other hand, it implements the joint Nord Stream 2 gas pipeline project connecting Russia with Germany, which will make the EU significantly dependent on the RF on energy issues, being not conducive to energy cooperation with Azerbaijan. Some important EU countries do not recognize the threat arising from the policy of Vladimir Putin. Thus, it can be seen 
that the Republic of Poland and other EU member states holding similar views still have a lot of work to make other members aware. Some changes in this regard have been visible for a long time, which may suggest that the third scenario has a greater chance of becoming reality, although the situation is so complicated and dynamic that especially in the medium and long run any of the above scenarios is possible.

\section{References}

1. ADAMUS, A., (2016) 6 faktów, które pomoga zrozumieć konflikt w Górskim Karabachu [6 facts that will help understand the Nagorno-Karabakh conflict] [www] Eastbook. Available from: https://www.eastbook.eu/2016/04/09/6-faktow-ktore-pomoga-zrozumiec -konflikt-w-gorskim-karabachu/ [Accessed 15/08/19].

2. BARABASZ, A. and PIECHOCKI, M. (2012) Partnerstwo Wschodnie jako instrument polityki wschodniej UE? [Eastern Partnership as an instrument of EU eastern policy?], Roczniki Integracji Europejskiej [Yearbooks of European Integration], No 6, Poznań, pp. 259-268.

3. BENEDYCZAK, J. et al. (2019) Wizja rozwoju Partnerstwa Wschodniego po 2020 roku [Vision of Eastern Partnership development after 2020], Warsaw: Polski Instytut Spraw Międzynarodowych.

4. CARLEY, P. (1998) Nagorno-Karabakh: Searching for a Solution [www] United States Institute of Peace. Available from: https:/www.usip.org/publications/1998/12/nagornokarabakh-searching-solution-0 [Accessed 10/07/19].

5. DASSONVILLE, C. (2019) The European Union and the Eastern Partnership: What if Europe built itself within its Borders as well? [www] The New Federalist. Available from: https://www.thenewfederalist.eu/the-european-union-and-the-eastern-partnership-what-ifeurope-built-itself [Accessed 20/07/19].

6. EASTERN PARTNERSHIP CIVIL SOCIETY FORUM, (2017) Eastern Partnership Index, Charting Progress in European Integration, Democratic Reforms, and Sustainable Development. Eastern Partnership Civil Society Forum. Available from: https:/eapcsf.eu/wp-content/uploads/EaP-Index-2017.pdf [Accessed 30/08/19].

7. EUROPEAN UNION. EUROPEAN COMMISSION (2004) Communication from the Commission European Neighborhood Policy Strategy Paper, Brussels: COM (2004) 373 
final, 12 May 2004. Available from: https://ec.europa.eu/neighbourhoodenlargement/sites/near/files/2004_communication_from_the_commission__european_neighbourhood_policy_-_strategy_paper.pdf [Accessed 5/08/19].

8. EUROPEAN UNION. EUROPEAN COMMISSION (2008) Communication from the Commission to the European Parliament and the Council Eastern Partnership, Brussels: COM (2008) 823 final, 3 December 2008. Available from: https://eurlex.europa.eu/LexUriServ/LexUriServ.do?uri =COM: 2008:0823: FIN:EN:PDF [Accessed 10/07/19].

9. EUROPEAN UNION. EUROPEAN COUNCIL, COUNCIL OF THE EUROPEAN UNION (2019) EU relations with Azerbaijan [www] European Council, Council of the European Union. Available from: https://www.consilium.europa.eu/en/policies/easternpartnership/azerbaijan/ [Accessed: 14/07/19].

10. FOX, B. (2018) Baku z nowym Jedwabnym Szlakiem połaczy Europe ze Wschodem [Baku with the new Silk Road will connect Europe with the East] [www] EurActiv. Available from: $\quad$ https://www.euractiv.pl/section/polityka-zagraniczna/news/baku-z-nowymjedwabnym-szlakiem-polaczy-europe-ze-wschodem/ [Accessed 5/08/19].

11. JAROSIEWICZ, A. and FALKOWSKI, M. (2016) Wojna czterodniowa w Górskim Karabachu [Four-day war in Nagorno-Karabakh] [www] OSW-Analizy [OSW-analyzes]. Available from: https://www.osw.waw.pl/pl /publikacje/analizy/2016-04-06/wojnaczterodniowa-w-gorskim-karabachu [Accessed 14/07/19].

12. KALICKA-MIKOŁAJCZYK, A. (2013) Ramy prawne i zasady unijnej Europejskiej Polityki Sasiedztwa wobec partnerów wschodnich [Legal framework and principles of the EU's European Neighborhood Policy towards Eastern Partners], Wrocław: Prawnicza i Ekonomiczna Biblioteka Cyfrowa.

13. KAPUŚNIAK, T. (2010) Wymiar Wschodni Europejskiej Polityki Sasiedztwa Unii Europejskiej. Inkluzja bez członkostwa? [The Eastern Dimension of the European Union's Neighborhood Policy. Inclusion without membership?], Warsaw: Centrum Europejskie Natolin.

14. MIZERSKA-WROTKOWSKA, M. (2011) Geneza i instytucjonalizacja Partnerstwa Wschodniego [The origin and institutionalization of the Eastern Partnership]. In: SZEPTYCKI, A. (ed.) Między sąsiedztwem a integracją. Założenia, funkcjonowanie $i$ 
perspektywy Partnerstwa Wschodniego Unii Europejskiej [Between neighborhood and integration. Assumptions, functioning and prospects of the Eastern Partnership of the European Union], Warsaw: Dom Wydawniczy Elipsa, pp. 43-63.

15. OSTAPENKO, E. (2019) 10th anniversary of the EU Eastern Partnership: what has changed for Azerbaijan? [www] EU Neighbours. Available from: https://www.euneighbours.eu/en/east/eu-in-action/stories/10th-anniversary-eu-easternpartnership-what-has-changed-azerbaijan [Accessed 12/07/19].

16. POLSKA AGENCJA PRASOWA (2006) Gazprom przejmie kontrole nad gazociagiem Iran-Armenia [Gazprom will take control of the Iran-Armenia gas pipeline] [www] Puls Biznesu [Pulse of Business]. Available from: https://www.pb.pl/gazprom-przejmiekontrole-nad-gazociagiem-iran-armenia-309631 [Accessed 11/07/19].

17. SADOWSKI, M. P. (2019) „Aksamitna” czy ,, kolorowa” rewolucja w Armenii? ["Velvet" or "colorful" revolution in Armenia?] [www] Nowa Konfederacja [New Confederation]. Available from: https://nowakonfederacja.pl/aksamitna-czy-kolorowa-rewolucja-warmenii/ [Accessed 16/07/19].

18. STAWARZ, P. (2017) Polityka Unii Europejskiej wobec państw Kaukazu Poludniowego [European Union policy towards the countries of the South Caucasus]. Unpublished thesis $(\mathrm{PhD})$, University of Warsaw.

19. STĘPNIEWSKI, T. (2011) Geopolityka regionu Morza Czarnego w pozimnowojennym świecie [Geopolitics of the Black Sea region in the Post-Cold War world], Lublin-Warsaw: Instytut Europy Środkowo-Wschodniej.

20. STRZELECKI, J. (2016) Eurazjatycka Unia Gospodarcza: czas kryzysu [Eurasian Economic Union: a time of crisis], Komentarze OSW [OSW-Comment], 195, 27 January 2016. Available from: https://www.osw.waw.pl/pl/publikacje/komentarze-osw/2016-0201/eurazjatycka-unia-gospodarcza-czas-kryzysu [Accessed 3/08/19].

21. WÓJCIK, T. (2013) 2013 - Upadek Nabucco. 2014 - Sukces TAP? [The fall of Nabucco. 2014 - TAP Success?] [www] BiznesAlert. Available from: https://biznesalert.pl/wojcikeuropa-poludniowo-wschodnia-kryzys-i-gazociagi-w-2013-r/ [Accessed 29/7/19]. 